\title{
Impact of Capital Expenditure on Working Capital Management: An Application on Hotel and Travel Companies Listed in Colombo Stock Exchange
}

\author{
Piriya Muraleetharan \\ Senior Lecturer, Department of Accounting, University of Jaffna, Jaffna, Sri Lanka
}

\begin{abstract}
This study is designed to examine on impact of capital expenditure on working capital management, an application on hotel and travel companies listed in Colombo stock exchange. Capital expenditure of the hotel and travel was used as the independent variable for the study whilst the dependent variables constituted some characteristic indicators that can affect the hotel and travel such as, net liquidity balance \& working capital requirement. Data was collected from 125 annual reports which are related to 25 hotel and travel listed in Colombo Stock Exchange for five years from 2012 to 2016.

Researcher used to regression analyze the data. Regression model was used for analyzing the relationship between Capital Expenditure and Working Capital Management for the sample firms. A significant negative relationship was found between net liquidity balance and Capital Expenditure, which implies that these firms don't increase the balance of most liquid assets when faced with capital expenditure since they don't have enough internally generated funds to be used in long term fixed investments. Furthermore, a significant negative relationship is also found between working capital requirement and Capital expenditure, which implies that these firms are efficiently managing the non-financial components to enhance their cash, balances to be used in speculative and operational activities.
\end{abstract}

KEYWORDS: Capital expenditure, Colombo Stock Exchange, net liquidity balance, working capital requirement

\section{INTRODUCTION}

Corporate finance basically deals with three decisions: capital structure decisions, capital Budgeting decisions and working capital management decisions. Among these, working Capital management is a very important component of corporate finance since it affects the Profitability and liquidity of a company. (Appuhami, 2008).

Every business needs investment to procure fixed assets, which remain in use for longer period. Money invested in these assets is called Long term Funds or Fixed Capital. Business also needs funds for short-term purposes to finance current operations. Investment in short term assets like cash, inventories, debtors etc., is called Short-term Funds or Working Capital. The Working Capital can be categorized, as funds needed for carrying out day-to-day operations of the business smoothly. The management of the working capital is equally important as the management of long-term financial investment. Accordingly WCM is mandatory requirement for all firms irrespective of the size and the country (developed and emerging) in which they are operating, it is of significantly important to the firms operating in the emerging countries. The firms in the emerging economies are typically small in size and they have limited access to the capital market or long term financing. These firms are heavily depending on the financing of the owner, trade credit and the short terms financing or loans provided by the banks to meet their investment in accounts receivable, cash and inventory.

The concept of working capital is based on the difference between fixed and circulating capital. Fixed capital was the money consumed in the acquiring of that which was sunk once for all into the business, while working capital was defined as such items as stock in trade, which are parted with and replaced by others in the ordinary course of business. The major distinction between fixed assets and current assets can be identified as a fixed asset will remain in the enterprise for two or more period while current assets will be used more rapidly, fixed assets will be charged over several periods while current assets are utilized rapidly in the business (Osisioma,1997).

Understanding the meaning of current assets and current liabilities is necessary for learning the meaning of working capital. It is rightly observed that "Current assets have a short life span.

Working capital management areas have been studied widely without considering financial constraint position of firm and capital investment's decision in last two decades. According to past literature cash flow and capital investment relation is fixed based on long-term financing policy of the firm, which determine the firm"s future profitability and financial structure.

\section{LITERATURE REVIEW}

Capital expenditure is the investment in fixed assets with longer lifespan and measureable monetary value, which involves enormous firm"s sources for longer term.

Dang (2007) stated that total amount of money spent on renovation, refurbishing, and replacing furniture, fixtures, and equipment (FF\&E) over a specific period of time, and the cost to correct or update obsolescence can be identified as capital expenditure. Other than the growth, leverage and the size of a company, type, and size of expenditures such as finance and operating and capital expenditure, have different impacts on working capital. 
Decisions of investment made on fixed assets or capital budgeting is the analysis process of business" long-term investment projects. Accordingly Capital expenditures plans are important for a firm in term of its future profitability. However the working capital is managing the short term financial investments or debt while the fixed capital decisions are planning long-term(Celik \& Boyacioglu, 2013)

Liu (2013) Stated that Capital expenditure is the investment made by firm to upgrade or acquire the physical asset with expectations of bringing potential profit to the firm, to maintain or to increase the scope of business operation.

Biddle \& Hilary (2006) revealed that capital investment has been seen as assets that may generate internal fund to the firm. Furthermore, the excess cash generated from capital investment is assumed that would not all be returned to the investor but certain amount is retained in the firm as fund for future investment. Investment in long-term asset may affect the cost of funding where the external financing leads to better liquidity position.

WC means the monetary arrangement which represents operating liquidity at hand to an entity, is known as WC. WC means the company"s CA minus current liabilities (CL). It has been known by financial managers as an important thought. There are several reasons behind this; one of them is that companies do not have adequate CA more likely confront the problem of short term source of finance and finds it problematic for their operation.

Valipour, Javad, \& Kobra (2012) Investigated that the impact of capital expenditure on working capital management of listed firms in Tehran stock exchange. For this purpose they used the net liquidity balance and working capital requirement as proxies of working capital management.

Raheman, Muhammad, \& Bushra (2012) examined the impact of capital expenditure on working capital management, the net liquidity balance and working capital requirement are used in form of proxies for the measurement of working capital management. Time period of 2004 to 2010 was selected for the study and include only cement, sugar and energy sectors for examinations.

Wang (2002) explained that reduction in corporate inventory and customer credit requirements may lower down sales volume, on the other hand expanding suppliers financing may decline discount percentage. Opportunity cost exceeds up to 20 percent, depending on the granted period and discounted percentage (Wilner, 2000). Contrary to conventional theories, adopting conservative policies (healthier investments) towards firm `s working capital may also result in firm`s financial benefits. Maintaining huge volume of inventory minimizes the possible intrusion cost during the production process and business loss caused by products deficiencies minimizes the cost of supply, and product price fluctuations (Blinder \& Maccini, 1991)

Shin \&Soenen (1998) proved the strong positive impact of trade credit reduction on firm`s profitability by taking a sample from US capital market for the period ranges from 1974 to 1994, though this relationship seems to be poor while conducting analysis at the industry level
Deloof (2003) studied Belgian firm`s for the period of 1992 to 1996, for the purpose of investigating relationship between average age of accounts receivable and firm`s financial performance, study indicated that reduction in average age of accounts receivable improves firm`s profitability, additionally it was stated that low profitable firms require long time durations to settle down their outstanding claims.

The decision-making process on the level of different working capital components has become frequent, repetitive, and time-consuming. Corporations are looking for new ways to stimulate growth, improve financial performance, and reduce risk in today"s challenging economic climate. Funds tied up in working capital can be seen as hidden reserves that can be used to fund growth strategies, such as capital expansion. Cash flows locked in stock and receivables can be freed up by understanding the determinants of working capital. Many organizations that have earned profits over the years have shown the efficient management of working capital (WCM).

Chiou, Jeng-Ren, \& Li (2006) conducted determinants of working capital management; they used the variables of working capital requirement and liquid balance. From the results it has found that the debt ratios and companies operating cash flows have impact on working capital management.

\section{Problem Statement}

Sri Lanka was the first South Asian country to formalize and recognize hotel and travel as an important industry and since then, hotel industry has grown steadily in a relatively uncompetitive region until our internal civil conflict began to take toll on the hospitality industry from around the late 1970s up until 2008. Sri Lanka's hotel and travel industry has shown an unprecedented growth with the impact of the peaceful environment. Many hotels have started making profit and are highly investing in their fixed assets to take best advantage of the industry's higher growth condition. In the meantime, many new hotels have been built and expand their hotel premises all over the country.

Therefore CE has a huge impact on working capital. In this study, it is argued that fixed assets investments and working capital management are two big financial planning which interrelated with each other and the relation between them is tried to be determined. Based on this study trying to investigate the impact of $\mathrm{CE}$ on working capital management with special reference to listed hotel and travel companies for the period of 2012-2016. There is lack of literatures in this area of study relating to working capital management of hotel and travel industry. Therefore this attempt will fill the knowledge gap in this area of study.

\section{Research Questions}

What is the impact of CE and the firm "s working capital in hotel and travel companies listed in Colombo stock exchange?

\section{Research Objectives}

To identify the impact of CE on working capital management with respect to net liquidity balance and working capital requirement in hotel and travels companies listed in Colombo stock exchange. 


\section{Methodology}

The study used secondary data collection methods which will be obtained from audited annual financial statements which include Company's income statement, statement of financial position and cash flow statement. Annual financial statements for hotel and travel companies were obtained from CSE web site.

This study was based on financial statements of the hotel and travel firms listed on the Colombo stock exchange. Twenty five hotel and travel companies were chosedn by using method. Sample of the study included only firms that had continuously traded over the period 2012 to 2016.

$\mathrm{CE}$ is identified as the independent variable in the investigation and includes expenditures incurred by firm for acquisition and upgrading physical assets, such as land, buildings, machinery, vehicles and equipment.

Investigation working capital management was measured by net liquidity balance (NLB) and working capital requirement (WCR). Accordingly NLB and WCR were identified as main dependent variables of the study in the investigation of impact of CE on working capital management.

\section{Hypothesis}

$\mathrm{H}_{1}$ : There is significant impact of capital expenditure and net liquidity balance

$\mathrm{H}_{2}$ : There is significant impact of capital expenditure and working capital requirement

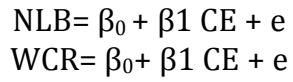

Where;

NLB - Net Liquidity Balance

WCR - Working Capital Requirement

$\mathrm{CE}$ - Capital Expenditure

E - Error term

\section{Data presentation and analysis}

Data analysis is a process of inspecting, cleansing, transforming and modeling data for discovering useful information, suggesting conclusions, and supporting decision-making( (Bihani \& Patil, 2014). impact of Capital Expenditure On Working Capital Management.

\section{Regression Analysis}

This study was used panel data regression analysis of crosssectional in order to measure the relationship between individual independent variable (CE) and dependent variables (NLB \& WCR).

According to the regression equation established to measure the impact of capital expenditure on working capital management in term of NLB and WCR, A large value indicates that a unit change in this predictor variable has a large effect on the criterion variable.

Table 1: Regression model summary of CE on NLB

\begin{tabular}{|l|l|l|l|l|}
\hline \multicolumn{1}{|c|}{ NLB } & \multicolumn{1}{c|}{ Coef. } & Std. Err. & T & P $>$ t \\
\hline CE & -0.3777 & 0.1633 & -2.31 & 0.022 \\
\hline Cons & 0.1386 & 0.0404 & 3.43 & 0.001 \\
\hline F(1,123) 5.35 & \multicolumn{4}{|c|}{ Prob> F 0.0224 } \\
R-Squared 0.0417 & \multicolumn{2}{|c|}{ Adj R-squared 0.0339 } \\
\hline
\end{tabular}

Above table shows that $\mathrm{R}^{2}$ value is 0.0417 which means that there is a variance of $4 \%$ and also indicated that $p$ value is 0.0224 which is lower than 0.05 . It shows that there is a significant impact of CE on NLB. And also that shows adjusted $\mathrm{R}^{2}$ value is 0.0339 which means that capital expenditure only by $3.3 \%$ on NLB and remaining $96.7 \%$ are determined by other factors. These table displays the results of the coefficient estimation for each performance measure studied. The impact of CE $(t=-2.31$ and $p=0.022)$, NLB of these firms are significant at the 5 percent level.

Table 2: Regression model summary of CE on WCR

\begin{tabular}{|l|l|l|l|l|}
\hline WCR & Coef. & Std. Err. & \multicolumn{1}{c|}{ T } & P $>$ t \\
\hline CE & -0.2599 & 0.0583 & -4.46 & 0.000 \\
\hline Cons & 0.0263 & 0.0144 & 1.82 & 0.071 \\
\hline F(1,123) 19.85 & \multicolumn{3}{|c|}{ Prob> F 0.0000 } \\
R-Squared 0.1389 & \multicolumn{4}{|c|}{ Adj R-squared 0.1319} \\
\hline
\end{tabular}

The above table shows that $\mathrm{R}^{2}$ value is 0.1389 which means that there is a variance of $13.89 \%$ and also indicated that $p$ value is 0.0000 which is lower than 0.05 . It shows that there is a significant impact of capital expenditure on WCR. The adjusted $\mathrm{R}^{2}$ value is 0.1319 which factors. Table displays the results of the coefficient estimation for each performance measure studied. The impact of CE $(t=-4.46$ and $p=0.000)$, WCR of these firms are significant at the 5 percent level.So These findings support the $\mathrm{H}_{1}$ and $\mathrm{H}_{2}$ hypothesis, thus accepting it. Similar results have been obtained in the previous research by (Appuhami, 2008).

\section{Conclusions}

The management of working capital is one of the most important financial decisions of a firm. Efficient level of working capital is a mandatory requirement for smooth running of business regardless of the nature of business. Working capital management focuses on company"s profitability and the risk. Inefficient management of working capital leads to over investment in working capital and reduces the profitability of the companies and in other way it leads to insufficient amount of working capital and results in financial difficulty, then putting the company at risk. The results of this study show capital expenditure has highly significant impact on working capital management.

\section{REFERENCES}

[1] Appuhami, B. R. (2008). The Impact of Firms" Capital Expenditure on Working Capital Management: An Empirical Study across Industries in Thailand. International Management Review, 4 (1).

[2] Biddle, G., \& Hilary, G. (2006). Accounting Quality and Firm-Level Capital Investment. The Accounting Review, 963-982.

[3] Bihani, P., \& Patil, S. (2014). A comparative study of data analysis techniques. International journal of Emerging trends and Fechnology in computer science.

[4] Blinder, A., \& Maccini, L. (1991). The resurgence of inventory research: what have we learned. Journal of Economic Survey, 5, 291-328.

[5] Celik, I., \& Boyacioglu, N. (2013). The Impact Of Fixed Assets Expenditures On Working Capital Management: An Application On Manufacturing Enterprises In Istanbul Stock Exchange. Journal of Süleyman Demirel University Institute of Social Sciences Year. 
[6] Chiou, Jeng-Ren, \& Li, C. (2006). The determinants of working capital management. The Journal of American Academy of Business, Cambridge, 149-155.

[7] CSE. (2018, march 08). Retrieved from Colombo Stock Exchange: http://www.cse.lk/home/market

[8] Dang, V. (2007). What were the major factors affecting hotel capital expenditures from 2000 to 2005. Toronto, Canada: Hospitality Valuation Services and Smith Travel Research.

[9] Deloof, M. (2003). Does working capital management affect profitability of Belgian firms. Journal of Business, Finance and Accounting, 30, 573-87.

[10] Liu, J. (2013). Fixed Investment, Liquidity, and Access to Capital Markets: New evidence. Intenational Review of Financial Analysis, 189-201.

[11] Osisioma, B. (1997). Sources and management of working capital. Journal of Management Sciences, 2. 48
[12] Raheman, A., Muhammad, K., \& Bushra, Z. (2012). Impact of Capital Expenditure on Working Capital Management in Selected Listed Pakistani Firms. American Journal of Scientific Research (53), 15-23.

[13] Shin, H., \& Soenen, L. (1998). Efficiency of working capital and corporate profitability. Financial Practice and Education, 8, 37-45.

[14] Valipour, H., Javad, M., \& Kobra, K. (2012). “The Impact of Capital Expenditure on Working Capital Management: Empirical Evidences from Tehran Stock Exchange. International Research Journal of Finance and Economics (85), 14-25.

[15] Wang, Y. (2002). Liquidity management, operating performance, and coroporate value: evidence from Japan and Taiwan. Journal of Multinational Financial Management, 12, 159-69.

[16] Wilner, B. (2000). The exploitation of relationships in financial distress: the case of trade credit. Journal of Finance, 55, 153-78.

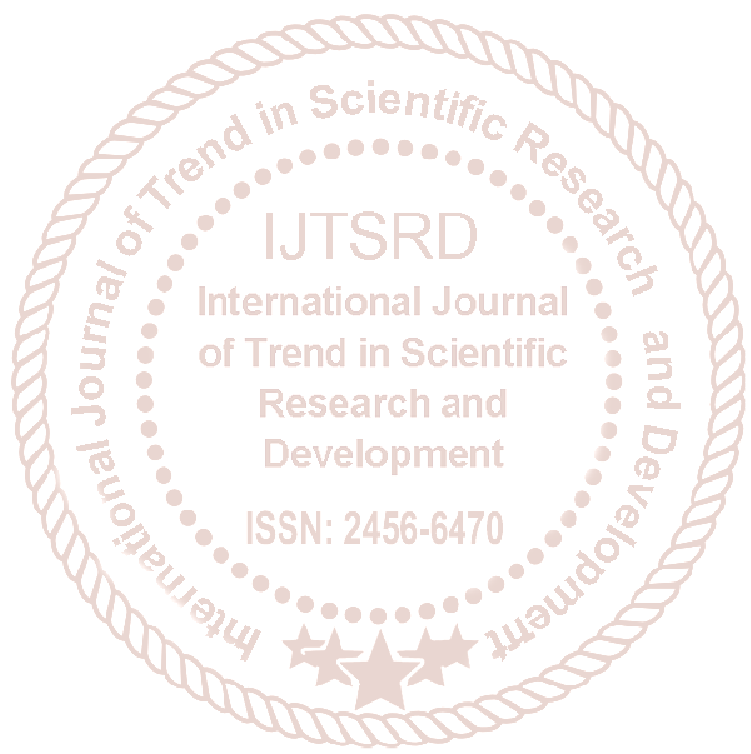

